Eixo Temático: Processos de Ensino-Aprendizagem

\title{
ET-06-005 \\ VISÃO DOS PROFESSORES DE BIOLOGIA SOBRE AVALIAÇÃO ESCRITA COMO RECURSO DETERMINANTE DA CONSTRUÇÃO DO CONHECIMENTO EM UMA ESCOLA PÚBLICA NA CIDADE DE CATU-BA
}

Akidauana Santos Silva ${ }^{1}$, Ariane Santa Rosa de Jesus ${ }^{1}$, Emile Lima dos Santos ${ }^{1}$, Magnólia Silva Queiroz $^{2}$

${ }^{1}$ Estudante de Licenciatura em Ciências Biológicas, pela Universidade do Estado da Bahia, Campus II.

${ }^{2}$ Professora assistente da Universidade do Estado da Bahia, Campus II.

http://dx.doi.org/10.21472/congrebio2016.et-06-005

\section{RESUMO}

Este estudo traz a percepção de professores sobre a avaliação no ensino de biologia em uma escola pública na Cidade de Catu-BA. Para isso, foram aplicados questionários contendo questões abertas que refletiam sobre a avaliação tendo como base a Lei de Diretrizes e Bases da Educação e os Parâmetros Curriculares Nacionais. A importância principal é compreender que o ensino de biologia vai muito além do que o conteúdo exposto no livro didático e, para a construção desse aprendizado envolve também experiências realizadas no cotidiano, portanto o método de avaliação da construção do aprendizado do discente deveria ser além da escrita, envolvendo o olhar do aluno e a relação interativa com o assunto abordado.

Palavras-chave: Avaliação; Construção; Aprendizagem.

\section{INTRODUÇÃO}

O ensino de Biologia tem a função de contribuir para o desenvolvimento de posturas e valores pertinentes às relações entre os seres humanos, entre eles e o meio, entre o ser humano e o conhecimento, contribuindo para uma educação que formará indivíduos sensíveis e solidários, cidadãos conscientes dos processos e regularidades de mundo e da vida, capazes assim de realizar ações práticas, de fazer julgamentos e de tomar decisões (BRASIL, 1999).

Para que esse ensino esteja em consonância com as novas tendências da educação é preciso que a avaliação utilizada pelo professor de biologia supere algumas barreiras, como a transferência dos conteúdos do livro didático para avaliação escrita, por exemplo.

Assim, é importante que o professor amplie seu entendimento de avaliação, já que este é um momento importante para o aluno e o professor, em que o processo de ensino e aprendizagem deverá ser refletido pelo professor. Segundo os Parâmetros Curriculares Nacionais (1998), a avaliação informa ao professor o que foi aprendido pelo aluno, fazendo-o pensar sobre a eficácia de sua prática educativa e orientando-o para intervenções necessárias. Isto significa refletir como determinado conteúdo foi absorvido pelo aluno e como contribuiu para construção do seu conhecimento e também para o docente analisar se os métodos utilizados por ele foram relevantes ou precisam de ajustes para contribuir com a formação do aprendizado do discente.

Portanto, é necessário que o professor utilize mais de uma forma de avaliar, não se restringindo somente as atividades escritas.

Assim, a presente pesquisa é um trabalho de investigação da disciplina Prática Pedagógica II do curso de Licenciatura em Biologia, vinculada à Universidade do Estado da 
Bahia - UNEB, Campus II e, foi realizada no Colégio Estadual, na Cidade de Catu-BA, onde o público diretamente envolvido foram três professores da disciplina biologia.

Sendo assim, o objetivo foi conhecer a visão de professores de biologiasobre a avaliação escrita no ensino desse componente curricularna cidade de Catu-BA.

\section{METODOLOGIA}

A presente pesquisa é de natureza qualitativa. A opção pela abordagem qualitativa é por acreditar que esta irá contribuir para uma explicação de uma realidade que está relacionada com o ensino de biologia.

De acordo com Ludke e André (1986, p. 18) “o estudo qualitativo é o que se desenvolve numa situação natural, é rico em dados descritivos, tem um plano aberto e flexível e focaliza a realidade de forma complexa e contextualizada”.

A metodologia da pesquisa foi baseada na realização davisita de campo. Durante a pesquisa foi elaborado e aplicado um questionário com cinco questões abertasa cinco professores buscando entender a visão destes quanto ao processo de avaliação no ensino de biologia.Assim, as questões refletiam como o ensino de biologia se inseriam quanto às concepções pedagógicas tradicionais e construtivistas para então pensar na avaliação tendo como base a Lei de Diretrizes e Bases da Educação, Lei n. 9394/96 e os Parâmetros Curriculares Nacionais (BRASIL, 1998). Antes da aplicação dos questionários, atendendo a preceitos éticos os professores concordaram com a participação na pesquisa, assinando o Termo de Consentimento Livre Esclarecido (TCLE).

As respostas dos professores foram organizadas em um texto.

\section{RESULTADOS E DISCUSSÕES}

Os professores expuseram suas opiniões referentes às suas vivências e experiências de acordo com o questionário. Assim, revelaram que o ensino de biologia é bastante vasto, contudo a falta de recurso principalmente laboratorial e de material por serpouco ou quase não existir, assim comoequipamentos danificados juntamente com a falta de substâncias químicas e de vidrarias limita ainda mais. Sendo assim, há a necessidade de avaliações comuns aplicação de testes e provas, tornando esse processo cansativo. Dessa forma, a avaliação processual se é observada de acordo com a nota exata que o estudante adquire nas avaliações aplicadas, não podendo ser questionado e não trabalhados outras possíveis formas de avaliação; com isso a avaliação é cumulativo e quantitativo, mas sendo prejudicial aos alunos que tem dificuldade, trazendo para a disciplina rótulo de dificuldade e de complexidade nos conteúdos trabalhados.

Leite e Kager (2009) ao pesquisarem os efeitos aversivos das práticas deavaliação da aprendizagem escolar informam que o modelo de avaliação adotado em grande parte das escolas tem contribuído comos altos índices de fracasso escolar, representado pela repetência, evasão e, também, a exclusão interna do aluno. Isso justifica a importância de trabalhos que revelem os efeitosdanosos do modelo tradicional de avaliação e apontem alternativas que valorizem condições favoráveis para a aprendizagem e o desenvolvimento do aluno.

Os professores entrevistados têmciência que o ensino de biologia abrange muito mais que os conhecimentos trabalhados em sala de aula. Portanto, vários aspectos devem ser levados em conta ao pensar na construção do conhecimento em biologia e a avaliação é um deles, pois o que foi aprendido pelo aluno, serve de reflexão para o trabalho do professor.

Aavaliação escrita não é o único instrumento que o docente deveria utilizar como método avaliativo, deste modo os professores acreditam que a avaliação referente a construção do conhecimento do aluno deve ser realizada processualmente analisando desta forma critérios como participação, envolvimento e dedução sobre o assunto trabalhado em conjunto na sala de aula, utilizando desta forma de atividades escritas apenas como forma quantitativa.

Segundo LUCKESI (1996), a avaliação que ocorre há muito tempo até os dias atuais nas escolas, é centrada nas provas que estão voltados para um modelo teórico de educação que 
reproduz a concepção de uma sociedade burguesa que pressupões que a educação garantirá a conservação e a reprodução desta sociedade.

Por fim os docentes entrevistados julgaram também haver uma grande deficiência neste processo de construção e avaliação do ensino de ciências biológicas, pois a granderealidade que muitos colégios enfrentam é a transferência repetitiva de conhecimento do professor para 0 aluno através do livro didático e o método de avaliação em sua maioria ocorre somente por meio da avaliação escrita, onde os alunos em sua maioria tornam-se apenas reprodutores do que está escrito nos livros, preocupando-se apenas com o valor quantitativo (nota) e não com a construção do conhecimento através do olhar crítico e das experiências realizadas no âmbito escolar e social.

\section{CONCLUSÃO}

Apesar das deficiências muitas vezes encontradas na estrutura escolar e no método de ensino a aplicação de exercícios avaliativos para a análise da construção do conhecimento do aluno, acredita-se que é possível e que se deve mudar o contexto atual de ensino, aprendizagem e avaliação do conhecimento para que criemos nos alunos de biologia um senso crítico cientifico e desmonte o tabu de que avaliação é apenas quantitativo (método de obter notas).

\section{REFERÊNCIAS}

BARBOSA, M. R. L. S.; MARTINS, A. P. R. Avaliação: uma prática constante e no processo de ensino e aprendizagem. Revista da Católica, v. 3, n. 5, p. 1-9, 2011. Disponível em: $<$ http://catolicaonline.com.br/revistadacatolica2/artigosv3n5/artigo27.pdf>. Acesso em: 28 abr. 2016.

BRASIL. Lei no 9.394, de 20 de dezembro de 1996. Estabelece as diretrizes e bases da educação nacional. Disponível em: <http://www.planalto.gov.br/ccivil_03/leis/L9394.htm>. Acesso em: 28 abr. 2016.

CARMO, S.; SCHIMIN, E. S. O ensino da Biologia através da experimentação. Disponível em: $<$ http://www.diaadiaeducacao.pr.gov.br/portals/pde/arquivos/1085-4.pdf $>$. Acesso em: 28 abr. 2016.

LEITE, S. A. S.; KAGER, S. Efeitos aversivos das práticas deavaliação da aprendizagem escolar. Ensaio: aval. pol.públ. Educ., v. 17, n. 62, p. 109-134, 2009.

LUCKESI, C. Avaliação da aprendizagem escolar. São Paulo: Cortez, 1996.

MELO, É. S.; BASTOS, W. G. Avaliação escolar como processo de construção de conhecimento. Est. Aval. Educ., v. 23, n. 52, p. 180-203, 2012 Disponível em: $<$ http://www.fcc.org.br/pesquisa/publicacoes/eae/arquivos/1735/1735.pdf >. Acesso em: 28 abr. 2016. 